\title{
The Effects of DNA Evidence on
}

\section{Homicide Cases in Court}

\author{
Michael Briody* \\ Griffith University, Australia
}

\begin{abstract}
This study examines the effects that deoxyribonucleic acid (DNA) evidence had on decisions in homicide cases as they progressed through the criminal courts. These effects were examined within a context of other evidentiary and extra-legal factors that may also have had a bearing on case outcomes. A sample of I 50 solved and completed cases referred by police for prosecution in the jurisdiction of Queensland was selected for examination. In half of these cases prosecutors produced DNA evidence to relate the accused to the crime, while the other half acted as a control group and did not include DNA evidence. Outcomes of the analyses were that cases with DNA evidence were much more likely to reach court than cases without, while incriminating DNA evidence demonstrated a powerful influence on juries' decisions to convict. Additionally, some extra-legal social factors such as age and gender of defendants or victims proved to be predictors of court outcomes at various stages. DNA was associated with a slightly decreased length of imprisonment for manslaughter offences. As with previous controlcomparison studies on sexual offences and serious assault cases, in homicide cases DNA evidence demonstrated no significant statistical relationship with guilty pleas.
\end{abstract}

Deoxyribonucleic acid, more commonly known by its acronym DNA, is the genetic material that encodes the entire hereditary information about each individual in almost every cell of the body. DNA is found in all cells with a nucleus and is the same throughout the body. The DNA molecule has a spiral or double helix structure, and virtually every human fluid or tissue contains some DNA that can be analysed through DNA profiling. Over time DNA is relatively stable, so that samples collected years ago can be compared to more recent samples. DNA is also resistant to many conditions that destroy most other biological materials, like proteins. The combinations of the four bases that constitute DNA are unique to each person, with the exception of identical twins. Although all humans share a significant majority of DNA, the remaining regions of the molecule are highly variable between individuals. These regions are exploited for forensic purposes by comparing the DNA profile from an unknown evidence sample to the DNA profile of a known individual or to other evidence samples. The regions compared are non-coding or "junk" DNA, and hence do not contain information relevant for protein synthesis, nor reveal information about an individual's other characteristics, such as predisposition to diseases (Inman \& Rudin, 1997, pp. 29-35).

Human DNA can be found in the nucleated cells in tissue, blood or skin, or in spermatozoa. It may be obtained from white blood cells or from epithelial cells that have sloughed off the skin, or from semen. For forensic purposes, residual material retrieved from crime scenes, from victims or suspects, or from objects, may be analysed for DNA, and in many cases profiled for identification purposes. In addition to cells from blood, tissue, bone and hair roots, cells from saliva may be found on items like cigarette butts, drinking vessels,

*Email: m.briody@griffith.edu.au 
balaclavas and toothbrushes, while hats, weapons, clothing and car steering wheels may yield skin cells. Locard's "Law of Contact" (1934) explains how any contact between two surfaces can result in an exchange of material, including DNA. Only small amounts of DNA are required, particularly where polymerase chain reaction (PCR) technology is used to amplify biological residue. Contaminants or degradation, however, can act to prevent a DNA profile being obtained (Speakman, 1999, p. 23; Wilson-Wilde, 2001, p. 4).

\section{Background}

In the last two decades, the use of DNA has been increasingly recognised internationally as a potential tool in criminal investigations. It has gained worldwide acceptance through both case precedents and the interpretation of statute law. The first use of DNA profiling in the criminal justice context was for two rape-murders in Narborough Village in the UK in the mid-1980s. Those cases demonstrated the vastly improved discriminatory power of DNA over the previous serological methods of blood type analysis. DNA testing excluded one suspect, Rodney Buckland, who had already confessed to one of the murders, and it eventually confirmed the identity of the offender, Colin Pitchfork (Wambaugh, 1989). The first completed case in Australia involving DNA evidence occurred in 1989 in a sexual offence case in the Australian Capital Territory (Coelli, 1989, pp. 22-26). Legislation in different countries, including the Criminal Investigations (Blood Samples) Act 1995 in New Zealand and various State statutes in Australia, has provided for the establishment of criminal reference DNA databases (Mobbs, 2001). Numerous instances can be cited worldwide where DNA evidence has been crucial to the solving and prosecution of homicide cases (Inman \& Rudin, 1997; Speakman, 1999).

This current study was conducted in Queensland, where two highly publicised cases in that state demonstrated the spectacular level of success that forensic DNA has achieved in particular homicides. These were the so-called "Catwoman" case and the 1983 Brampton Island murder. On 1 March 1998, Kathleen Marshall, aged 52, a prominent veterinarian and director of the Cat Protection Society of Queensland, was found dead in the downstairs surgery of her home. She had suffered multiple stab wounds. Samples of blood splattered around the surgery were taken for analysis. No witnesses or weapon were found and police interviewed numerous associates and nearby residents, taking many blood samples for analysis. One of the last of those interviewed was Andrew Fitzherbert, a palmist who worked out of a spiritualist church. Fitzherbert denied knowing Marshall or ever being in her home, nor was there any record of them meeting, but Fitzherbert refused to provide a blood sample. Investigators applied to a magistrate for permission to take such a sample, but were refused on the grounds that this would constitute an invasion of privacy. Perhaps oddly, the magistrate did not see such problems in granting a search warrant on Fitzherbert's house, where investigators retrieved a handkerchief from which they took mucus for analysis. The DNA profile from the mucus matched tiny spots of blood left at the crime scene. A Supreme Court jury convicted Fitzherbert after it heard that the chances of the blood at the scene belonging to anyone else were $14 \times 10^{15}$ to 1 . Fitzherbert's later appeal against the conviction was rejected (Oberhardt, 1999, p. 3, 2000a, p. 11; Scott, 1999, p. 9).

At Brampton Island on the Great Barrier Reef on 2 September 1983, the body of resort worker Celia Douty, aged 41, was found bludgeoned to death and her head covered with a towel. Police interviewed more than 300 guests and visitors on the island. There were no witnesses to the crime and no confession, but for 18 years police suspected Sydney motor industry finance manager, Wayne Butler, of the crime after a family member contacted them. The techniques for the DNA profiling were not sufficiently advanced to provide proof until more recently, when on the strength of DNA evidence, Butler was committed to be tried in 2001. The court heard that Douty, a waitress, had gone sunbaking at idyllic Dinghy 
Bay as she often did on her day off. Butler, who was holidaying in north Queensland at the time, made a day-trip to the island, where he went walking and exploring alone for 4 hours the day Douty died. DNA evidence confirmed semen stains on the towel covering Douty's body as coming from Butler, and that the chances of another member of the community having the same profile were given as 1 in $23 \times 10^{15}$.

Dr Kary Mullis, who won a Nobel Prize in Chemistry for devising methods for DNA replication, advised the defence throughout the trial, although he was not called to testify. Associate Professor Leo Freney, supervisor of Queensland Health's Forensic Laboratory, provided testimony on DNA matches for the Crown and was supported by Dr Bruce Budowle, Senior Scientist at the FBI Laboratory. The defence suggested that the DNA evidence had been contaminated in the laboratory, but the prosecution successfully rebutted this allegation by demonstrating that this was not possible. The jury found Butler guilty, after which Supreme Court Judge Justice John Helman declared, "Butler, this is a savage crime for which the penalty is mandatory. You will go to prison for life" (as cited in Thomas, 2002, p. 28). (See also Hansen, 2001, p. 15; Nolan, 2001, p. 12; Oberhardt, 2001, p. 3).

\section{Previous Studies}

No other quantitative research was located that dealt specifically with the influence of DNA evidence on homicide case outcomes. Previous criminological studies have examined the effects of forensic evidence, and to a limited extent of DNA evidence, but space does not allow a comprehensive review of these. An extensive US study pre-DNA found that "conviction rates, in two [of the four] jurisdictions studied, are significantly higher in homicide cases where physical evidence linking the offender with the crime is developed" (Peterson et al., 1984, p. xvii). A later US study analysed 28 cases, including some homicides, where DNA evidence was used to help establish innocence after trial (Connors et al., 1996). In Australia at the University of Melbourne, Jane Taupin's (1994) MA research thesis dealt primarily with measuring the impact of DNA on sexual offences in Victoria. A survey conducted in the UK to assess the effectiveness on volume crime of the national DNA database that had commenced operating in 1995 provided only anecdotal accounts of cases where DNA was successfully used in serious crime (Speakman, 1999). Tracy and Morgan (2000) adopted a more critical perspective of forensic DNA using a quantitative approach. They concluded that DNA would make little difference in the US to either serious crime or property crime: serious crime was already thoroughly investigated with a high proportion of such offences being solved, while trace DNA was associated with only a small minority of property offences and rarely used when prosecuting them (Tracy \& Morgan, 2000, pp. 648-650). The theme of the effects of DNA on sexual offences in Australia was revisited by this author, and incriminating DNA evidence was found to be a predictor of both cases reaching court and of jury convictions (Briody, 2002a, 2002b). The present article extends the assessment of the effects of DNA evidence in court to homicide offences. However, it replicates a previous paper on sexual offences to some degree by using similar methods and in its reporting of statistical results. This uniform approach can be advantageous in that it facilitates a cross-comparison of results between different offence types.

\section{Hypotheses to Test}

The highly publicised Queensland cases outlined earlier in this article are examples of the probative value that DNA evidence may have in court, and its potential in possibly influencing pre and post-court outcomes. However, given the absence of any comparative Australian studies that have actually examined the effects of DNA on homicide court cases, 
it is uncertain from anecdotal evidence alone whether the absence or presence of DNA has any bearing on the outcome of homicide cases in the criminal justice process overall. The purpose of this study is therefore to examine the effects of DNA evidence on homicide cases in court by testing the following hypotheses:

- that a higher proportion of homicide cases would reach court where DNA evidence was presented by prosecutors

- that more guilty pleas would result where suspects were confronted with DNA evidence associating them with victims, with exhibits such as weapons, or with crime scenes

- that a significant relationship would be found between DNA evidence implicating the accused and the likelihood of a conviction by juries

- that longer custodial penalties would be imposed where incriminating DNA evidence was presented.

The hypothesis relating to the sentencing phase was included due to an earlier finding that DNA evidence showed a significant statistical association with sentencing (Briody, 2002b, p. 177), and to the positive relationship between forensic evidence and sentencing found during research in the United States by Peterson et al. (1987, p. 1730).

\section{Method}

After the appropriate ethical permissions had been obtained, a sample of 150 homicide cases was used in order to analyse the effects of DNA evidence on such offences in the court process. Seventy-five homicide cases that utilised DNA evidence were selected from Queensland Health's forensic biology laboratory files. These cases were the maximum number available at the time of selection where a directly incriminating link was made through DNA testing between the suspect and either the victim, the crime scene, or a weapon proven to be used by the accused in the offence. The 75 cases covered offences that occurred between 14 January 1996 and 3 December 1999. The last date was the most recent case for which results through to the Court of Appeal were available when data were collected from the forensic laboratory in 2001 . Proceeding back in time, every available DNA case file was scrutinised and included if it met the further selection criteria:

- that the cases be completed so that they could be tracked to finality in the justice process (i.e., to the appeal stage in the courts)

- that a forensic laboratory scientist had produced a sworn court statement in which the defendant was associated through DNA profiling with either the victim or the crime scene

- that no defendants were subject to penalties for juveniles (which can be different from those for adults)

- that police and court records could be located

- that no cases referred to the Mental Health Tribunal were included, as these were not adjudicated by the criminal courts.

A control group of 75 other homicide cases was then chosen from the computerised records of the Queensland Police Service (QPS). They were taken from within the same time bracket and jurisdiction in order to place them in a contemporaneous social and legal context and to meet the same selection criteria except for the second. This control group was not a random sample but was selected to mirror the DNA group as far as possible, in order to minimise biases when conducting comparisons. Data on court outcomes were accessed through the QPS Police Information Centre during 2002. The sample population of 150 cases was of sufficient size in relation to the number of independent variables to allow significant relationships to be calculated statistically, although not all of these variables were available for every case (Tabachnick \& Fidell, 2001, pp. 521-522). 
A binary division of offence seriousness was used throughout, where "1" was the higher in the two-level hierarchy of offences (murder) and " 0 " was allocated to the lesser offence (manslaughter). This dichotomy was suitable for direct insertion into the later logistic regression analyses. A measure of parity between both groups in the sample was for the seriousness of the offence. This was done to ensure that incidents referred for DNA analysis were not significantly more serious that those selected for the control group. A higher percentage of DNA cases (65\%) retained the murder charge in comparison to the control group (58\%), but this did not rate as statistically significant in a bivariate analysis.

A listing of descriptors of the independent or predictor variables for the cases sampled is set out in Table 1, along with their means and standard deviations where applicable. The independent variables are divided into four general categories: victim variables, offence variables, evidence variables and defendant variables. Social data, such as age, race and gender of victims and accused were obtained from QPS records and included, as these may have had a bearing on case outcomes (White \& Perrone, 1997, pp. 91-101). Relationships between defendants and victims were included as independent variables. A strong body of criminological research has demonstrated the relevance of these relationships (Mouzas, 2000; Polk, 1994). Very few homicides in the sample were found to have occurred between strangers, leaving the relationship in the remaining 120 cases where it could be found to be dichotomously classified as "known" to one another, or "enmeshed". The latter is a broad term used to include married or de facto partners, ex-partners and parents-children. Examples in the sample were a female who killed her sister's partner while intervening in a domestic dispute, and another who killed her mother's defacto.

Categories omitted as independent variables were photographic evidence and "tangible" evidence such as a deceased victim, because both of these factors were found present in all but one or two cases and constituted a lack of variability. Apart from where indicated in Table 1 , most predictor variables were binary, with the value of 1 reflecting inclusion in the category. As not all data were available for every case from the records accessed, one column indicates the number of cases for each variable where data could be found. The first variable is described as measuring whether the victim was male. This variable was ascertained in 149 cases; the mean of 0.65 indicates that 65 percent of the 149 victims (that is, 97) were male. Thirty-five percent (52) were female, and the remaining 1 unknown. SD is the standard deviation, and the minimum value of the variable is 0 (female) while the maximum is 1 (male).

Two variables were initially coded as scale variables: defendant race and defendant statement. The former used a three-part classification for race: Caucasian, Indigenous and Other. These were recoded dichotomously using dummy variables by classifying defendants as Caucasian or not ( 1 or 0$)$, Indigenous or not ( 1 or 0$)$, and so on. Similarly, the 4-scale classification for defendant statement was recoded onto "confessed or not" (1 or 0$)$, " denied committing offence" or not ( 1 or 0$)$, and so on. The ages of the victim and defendant at the time of the offence were initially recorded in years. These were also later collapsed into binary form, with median ages of 35 years for victims and 30 for defendants as the divide. Hence ages for victims 35 years of age or less at the time of the offence were coded as 0 , and those aged 36 years or more as 1 . The study did not assess the relative effects of the different types of DNA profiling technology used over the period from which cases were selected.

The applicability rate of DNA evidence to homicide investigations was estimated during selection. Of a total of 69 homicide incidents reported during 1998-99 in Queensland, 13 cases $(19 \%)$ produced DNA evidence with probative value for investigators (QPS CRISP; Forensic Biology Section Case Files). For information on the general circumstances, characteristics and trends for homicides in Australia, the National Homicide Monitoring 
Program that has been instituted in Australia over the last decade should be consulted (Mouzos, 2002a, 2002b).

\section{TABLE 1}

Independent Variables Examined: 150 Homicide Cases

\begin{tabular}{|c|c|c|c|c|c|}
\hline Variable Name & No of valid Cases & Mean & $S D$ & Min & Max \\
\hline Victim is male ( $0=$ female, $1=$ male $)$ & 149 & 0.65 & 0.48 & 0 & 1 \\
\hline Victim age at fime of offence (years) & 138 & 36 & 17.5 & 1 & 85 \\
\hline Victim race ( $0=$ Cauc., $1=$ Indig., $2=$ Other $)$ & 134 & & & 0 & 2 \\
\hline \multicolumn{6}{|l|}{ Offence Type } \\
\hline Most serious offence charged & 148 & 0.61 & 0.49 & 0 & 1 \\
\hline $0=$ Manslaughter & 57 & & & & \\
\hline $1=$ Murder & 91 & & & & \\
\hline \multicolumn{6}{|l|}{ Evidence Variables } \\
\hline Fingerprints (1 = present) & 140 & 0.26 & 0.44 & 0 & 1 \\
\hline DNA court statement ( 1 = present) & 150 & 0.49 & 0.50 & 0 & 1 \\
\hline Independent witness(es) to offence (1 = present) & 140 & 0.27 & 0.45 & 0 & 1 \\
\hline \multicolumn{6}{|l|}{ Defendant Variables } \\
\hline Defendant age at time of offence (years) & 145 & 31 & 10.3 & 14 & 59 \\
\hline $\begin{array}{l}\text { Defendant employed at time of arrest } \\
(1=\text { employed })\end{array}$ & 143 & 0.27 & 0.45 & 0 & 1 \\
\hline Defendant race & 147 & & & 0 & 2 \\
\hline $0=$ Caucasian & 88 & & & & \\
\hline 1 = Indigenous & 41 & & & & \\
\hline 2 = other & 18 & & & & \\
\hline Defendant is male $(0=$ female, $1=$ male $)$ & 148 & 0.82 & 0.38 & 0 & 1 \\
\hline Defendant statement: & 121 & 2.00 & 1.07 & 0 & 3 \\
\hline $0=$ denies committing offence & 11 & & & & \\
\hline 1 = makes no statement/refuses interview & 36 & & & & \\
\hline 2 = makes some admis sions & 16 & & & & \\
\hline $3=$ confesses to offence & 58 & & & & \\
\hline $\begin{array}{l}\text { Defendant has prior corvictions for violence } \\
\text { (1 = has priors) }\end{array}$ & 132 & 0.48 & 0.50 & 0 & 1 \\
\hline Defendant-victim relationship & 120 & & & & \\
\hline Defendant male known to victim & 56 & & & & \\
\hline Defendant male enmeshed with victim & 41 & & & & \\
\hline Defendant female known to victim & 6 & & & & \\
\hline Defendant female enmeshed with victim & 17 & & & & \\
\hline
\end{tabular}




\section{Effects of DNA Evidence on the Court Process: Data Analysis}

To gauge the effects of DNA evidence on the various decision-making stages in the courts a multivariate technique was employed. Dichotomous dependant variables were defined as:

- whether the case reached court (coded as 1$)$ or did not (coded as 0$)$

- whether the accused pleaded guilty (coded as 1 ) or did not (coded as 0 )

- whether the accused was found guilty through jury trial (coded as 1 ) or was not (coded as 0$)$.

The only scale variable was length of custodial penalty in manslaughter cases, as those found guilty of murder were subject to the mandatory life penalty. Prior to 1 July 1997, those serving the life penalty were not eligible for parole for 13 years, and after that date, 15 years, while for two murders the penalty was 20 years.

A series of bivariate analyses was conducted to explore the relationship between each predictor variable and the dependent variables. These were then followed by logistic regression analyses to provide likelihood ratios and predictor equations, and by a multiple regression analysis to examine custodial penalty lengths for the manslaughter cases.

\section{Results of Statistical Analyses}

Table 2 presents the bivariate Pearson correlation coefficients examined to determine the significance of these relationships.

In the Magistrates' Court, cases were not proceeded with through either "no evidence to offer" (NETO) or a "no true bill". In the district court they did not reach court because of a nolle prosequi being entered. For the outcome in the first column - whether or not cases reached court - four independent variables were significantly correlated. These were, in decreasing order of strength, DNA evidence, the defendant making no statement to police or refusing an interview, the defendant confessing and the defendant's sex. While three of these variables were significantly positively correlated with cases being prosecuted, the defendant's refusing an interview showed a negative correlation.

The outcome examined in the second column - whether or not the defendant entered a plea of guilty - produced seven independent variables that were significantly correlated, but these did not include DNA evidence. Two of these were positive: a confession to the police by the defendant and if defendants or victims were Indigenous. Negative correlations with guilty pleas were victim age; that is, cases concerning murders of older victims were less likely to produce guilty pleas, defendants being Caucasian, cases where defendants made no statement to police and cases where the charge was murder. Defendants were less likely to plead guilty to murder, presumably because of the life sentence they would face. However, the correlation also reflects the outcomes of plea-bargaining, where murder charges were nolled by the DPP, then followed by a manslaughter charge and guilty plea.

For the outcome in the third column - cases in which the accused faced a jury trial and was convicted - nine independent variables were significantly correlated. DNA evidence was the most significant positive among these, and the only variable with $p<.01$. Other significant evidentiary variables were the fingerprints of the accused that had probative value and a confession or a denial by the accused when interviewed. The remaining correlations were social factors: victim sex and race, and the race of the accused. These were negative in value - meaning that, in the case of victim sex and race, juries were more likely to convict where the victim was female or Caucasian. Similarly, Caucasians were 
significantly more likely than Indigenous persons to be found guilty by a jury, although as shown in the second column, Indigenous accused were significantly more likely than Caucasians to plead guilty.

\section{TABLE 2}

Bivariate Pearson Correlation Coefficients Between Dependent and Independent Variables - Court Processing of Homicide Cases

\begin{tabular}{|c|c|c|c|}
\hline \multirow{2}{*}{$\frac{\text { Independent Variables }}{\text { Description }}$} & \multirow{2}{*}{$\begin{array}{l}\text { Disposition } \\
\text { Reached court } \\
(N=150)\end{array}$} & \multicolumn{2}{|c|}{ Court Outcome } \\
\hline & & $\begin{array}{l}\text { Guilty Plea } \\
(N=142)\end{array}$ & $\begin{array}{l}\text { Convicted by } \\
\text { Jury }(N=92)\end{array}$ \\
\hline Victim age & -.076 & $-.234^{* *}$ & .115 \\
\hline Victim sex & -.045 & -.107 & $-.233^{*}$ \\
\hline Victim race & .002 & $.181^{\circ}$ & $-.183^{*}$ \\
\hline Fingerprint evidence & -.041 & .088 & $.196^{\circ}$ \\
\hline DNA evidence & $.230^{* *}$ & .100 & $.405^{* *}$ \\
\hline Defendant oge & .020 & .062 & .090 \\
\hline Defendant sex & $.140^{\circ}$ & -.031 & .138 \\
\hline Deft. male known to victim & .076 & -.062 & .000 \\
\hline Deft. male enmeshed with victim & -.062 & .062 & .165 \\
\hline Deft. female known to victim & -.080 & .018 & .124 \\
\hline Deft. female enmeshed with victim & .025 & -.005 & $-.267^{*}$ \\
\hline Defendant employment & .059 & -.055 & .051 \\
\hline Defendant Caucasian & .003 & $-.166^{\circ}$ & $.240^{*}$ \\
\hline Defendant Indigenous & -.017 & $.174^{*}$ & $-.229^{*}$ \\
\hline Defendant other race & .019 & .010 & -.053 \\
\hline Defendant confessed & $.151^{*}$ & $.183^{*}$ & $.248^{*}$ \\
\hline Defendant made admissions & .018 & -.001 & .028 \\
\hline Defendant denies offence & -.003 & -.030 & $-.244^{*}$ \\
\hline Defendant makes no s tatement & $-.180^{*}$ & $-.186^{*}$ & -.125 \\
\hline Prior record violence & .014 & -.103 & -.023 \\
\hline Independent witness & .057 & .061 & -.085 \\
\hline Most serious offence & -.118 & $-.369^{* 4}$ & -.007 \\
\hline
\end{tabular}

Nole: $" p<.05 ; " p<.01$.

Caucasian. Similarly, Caucasians were significantly more likely than Indigenous persons to be found guilty by a jury, although as shown in the second column, Indigenous accused were significantly more likely than Caucasians to plead guilty.

A second group of bivariate correlations was calculated in Table 3 for the sentencing phase for manslaughter offences because additional independent variables had arisen from the previous court decisions that might affect sentencing. The variables were whether the accused pleaded guilty or, alternatively, was found to be guilty by a jury. Of the 150 cases sampled, 11 had no evidence to offer (NETO) in the magistrates' courts or were finalised through a nolle prosequi in the higher court, resulting in 139 cases reaching court. In 8 of the 150 cases, records accessed did not indicate whether finalisation was through a plea or 
trial. Of the 142 known cases, 47 pleaded guilty, and of the remaining 95, 3 were nolled, leaving 92 to be decided by juries. In 33 of these cases juries acquitted, with convictions made in the remaining 59. The overall result was 112 convictions (guilty pleas plus jury decisions) and 38 non-convictions (jury acquittals plus NETO/nolles). Murder convictions numbered 64 and manslaughter convictions numbered 48. For all 112 convictions the offender was incarcerated. Table 3 displays the correlations between the independent variables and the sentencing outcomes for the 48 manslaughter convictions. Murder convictions were not analysed because the independent variables could not influence the mandatory life sentence.

\section{TABLE 3}

Bivariate Pearson Correlation Coefficients Between Dependent and Independent Variables - Sentencing Stage Manslaughter Offences

\begin{tabular}{lc}
\hline Independent Variable & Length of Penalty Manslaughter Offences (N= 48) \\
\hline Victim age & -.046 \\
Victim sex & -.213 \\
Victim race & -.032 \\
Fingerprints & $.300^{*}$ \\
DNA evidence & $-.350^{* *}$ \\
Defendant age & .107 \\
Defendant sex & $.342^{* *}$ \\
Deff. male known to victim & .007 \\
Deft. male enmeshed with victim & .263 \\
Deft. female known to victim & -.150 \\
Deff. female enmeshed with vidtim & -.218 \\
Defendant employment & .234 \\
Defendant Caucasian & .111 \\
Defendant Indigenous & .014 \\
Defendant other race & .172 \\
Defendant confessed & .048 \\
Defendant made admissions & -.145 \\
Defendant denied offence & -.232 \\
Defendant made no statement & .192 \\
Prior record violence & $.367^{* *}$ \\
Independent witnesses & .000 \\
Guilty plea & $-.362^{* *}$ \\
\hline
\end{tabular}

Nole: $" p<.05 ; " p<01$.

Following these bivariate analyses, multivariate analyses were conducted. Table 4 shows the results of the logistic regression analyses. Logistic regression models were created using SPSS version 9.0 for Windows software. Variables found to have a significant relationship in the bivariate analyses were entered to create a full model and then those that were not predictive were removed. In the reduced model, only the independent variables that were statistically significant below the .10 level were retained (Poulos, 1993, p. 26). By being incorporated simultaneously in the model, the variables controlled for each other's effects. 
TABLE 4

Significant Predictor Variables from Logistic Regres sion Analysis: Homicide Cases

\begin{tabular}{|c|c|c|c|c|c|c|c|}
\hline \multirow[t]{2}{*}{ Court Process } & \multirow[t]{2}{*}{ Predictor } & \multirow[t]{2}{*}{ Beta } & \multirow{2}{*}{$\begin{array}{c}\mathrm{Sig} \\
\text { of Beta }\end{array}$} & \multirow[t]{2}{*}{$S E$} & \multirow{2}{*}{$\begin{array}{l}\text { Odds } \\
\text { ratio }\end{array}$} & \multicolumn{2}{|c|}{$95 \% \mathrm{Cl}$} \\
\hline & & & & & & Lower & Upper \\
\hline Reached court & Defendant sex & 1.5 & .0364 & 0.73 & 4.61 & 1.10 & 19.30 \\
\hline \multirow[t]{3}{*}{$(N=148)^{\prime}$} & DNA & 2.69 & .0135 & 1.09 & 14.69 & 1.74 & 123.99 \\
\hline & Constant $\left(\mathrm{B}_{0}\right)$ & 0.65 & .1703 & 0.63 & & & \\
\hline & $\begin{array}{l}93 \% \text { cases correctly } \\
\text { classified } \\
\text { Pseudo } R^{2}=20.7 \% \\
\chi^{2}=13.14 \text { (sig. } .0014\end{array}$ & & & & & & \\
\hline \multirow{6}{*}{$\begin{array}{l}\text { Guilty Plea } \\
(N=103)^{\prime}\end{array}$} & Victim age & -1.38 & .0041 & 0.48 & 0.25 & 0.10 & 0.65 \\
\hline & $\begin{array}{l}\text { Deff t makes no } \\
\text { statement }\end{array}$ & -1.26 & .0250 & 0.56 & 0.29 & 0.10 & 0.85 \\
\hline & Seriousness of offence & -1.44 & .0030 & 0.48 & 0.24 & 0.09 & 0.61 \\
\hline & Def't Indigenous race & 0.91 & .0684 & 0.50 & 2.48 & 0.93 & 6.60 \\
\hline & Constant $\left(\mathrm{B}_{0}\right)$ & 0.94 & .0574 & 0.49 & & & \\
\hline & $\begin{array}{l}75 \% \text { cases correctly } \\
\text { classified } \\
\text { Pseudo } R^{2}=29.6 \% \\
\chi^{2}=25.00 \mid \text { sig. } .0000\end{array}$ & & & & & & \\
\hline Jury convicts & Victim sex & -1.68 & .0509 & 0.86 & 0.19 & 0.03 & 1.01 \\
\hline \multirow[t]{6}{*}{$(N=63)^{\prime}$} & Fingerprints & 3.96 & .0175 & 1.67 & 52.62 & 2.00 & 1385.17 \\
\hline & DNA evidence & 3.14 & .0025 & 1.04 & 23.09 & 3.01 & 176.87 \\
\hline & Defendant confesses & 1.93 & .0248 & 0.86 & 6.01 & 1.28 & 37.40 \\
\hline & Defendant denies & -2.91 & .0328 & 1.36 & 0.05 & 0.00 & 0.79 \\
\hline & Constant $\left(B_{0}\right)$ & 0.05 & .9551 & 0.88 & & & \\
\hline & $\begin{array}{l}81 \% \text { cases correctly } \\
\text { classified } \\
\text { Pseudo } R^{2}=54.7 \% \\
\chi^{2}=31.84 \text { (sig. } .0000\end{array}$ & & & & & & \\
\hline
\end{tabular}

Note: 'Not all data were available for every case. Although juries were known to have decided 92 of the 150 cases, for example, data for the five independent predictor variables were found for only 63 of those cases. The larger confidence intervals for the independent variables DNA and fingerprints are wide because of the small number of cases on which the regression model is based, and the associated large standard errors.

In Table 4, the "Predictor" column displays the independent variables that most strongly influence the court process listed in the left column. The "Beta" column shows the logistic regression coefficient, "SE" is the standard error, while the "Odds ratio" is the exponentiate of the Beta value. The "Odds ratio" indicates the likelihood of a particular outcome where a designated variable is present in a case. For example, cases involving male suspects were more likely to reach court than those involving female suspects - the odds of reaching court were 4.61 times higher for males than for females. Cases where incriminating DNA evidence was available were also more likely to reach court: the odds being more than 14 (14.69) times higher for DNA cases than for non-DNA ones. The lower and upper 95 percent confidence intervals are reported for the odds ratio results. 
"Predicted probabilities" provides a percentage of how accurately the model will correctly classify cases overall. For example, in 100 cases where both the presence or otherwise of DNA evidence and defendant sex is known, the model would correctly predict for 93 cases whether cases would reach court. The fact that the model does not correctly classify $7 \%$ of the cases indicates that the court outcome is based on additional pieces of information not included in the logistic regression model. These may include other known independent but nonsignificant variables, or other facts relevant to the case that did not fit into the statistical categories collected. A pseudo measure of explained variation (Nagelkerke R2) is provided. For cases that reached court this value was $20.7 \%$.

DNA evidence in homicide cases acted as a statistically significant predictor for cases reaching court, along with the gender of the defendant - males being more likely to go to trial. The point at which DNA evidence assumed its greatest strength in homicide cases was in its influence on jury decisions, where it emerged as a powerful predictor of jury findings. A jury was far more likely to convict where prosecutors produced DNA evidence than when they did not - the odds of a conviction were more than 23 (23.09) times higher for cases with DNA than for those without. The other powerful predictor of jury decisions was probative fingerprint evidence, where the odds ratio was greater than 50 (52.62). Juries gave greater credence to physical evidence over the testimonial evidence of the accused. If the defendant had confessed to police in a record of interview, a conviction was more likely the odds of a conviction were close to six (6.01) times higher in cases with confessions than for cases without. However, where defendants denied guilt to police, convictions were far less likely — the odds for a conviction were 20 times less than in cases without such denials.

One social variable that acted as a predictor of a guilty finding was if the victim was male. This reduced the chances of a conviction significantly, probably due, as discussed below, to the number of domestic killings where the female accused was exonerated. As with both sexual offences and serious assaults (Briody, 2002b, 2002c), DNA evidence demonstrated no significant effect in homicide cases on inducing guilty pleas or as a predictor of such pleas. DNA evidence showed only a low positive statistical correlation of .01 with pleas of guilty (Table 2).

\section{Predicting Court Outcomes}

Table 5 gives examples to illustrate the effects of DNA evidence as a statistical predictor of the conditional probability of cases reaching court and of jury convictions. These were the two stages in the court process where DNA demonstrated a statistically significant predictive effect. To calculate the conditional probability for a dichotomous outcome when individual case characteristics are known, the formula used is:

$$
\text { Probability }=\frac{1}{1+\mathrm{e}^{-\operatorname{logit}}}
$$

where the logit $=\mathrm{B}_{0}+\mathrm{B}_{1} \mathrm{X}_{1}+\mathrm{B}_{2} \mathrm{X}_{2}+\mathrm{B}_{3} \mathrm{X}_{3} \ldots+\mathrm{B}_{\mathrm{k}} \mathrm{X}_{\mathrm{k}}$

$\mathrm{B}$ is the Beta value from Table 4, with $\mathrm{B}_{0}$ the constant. Table 5 shows case examples demonstrating both significant and minor differences that DNA evidence can make to jury decisions.

Table 5 illustrates how DNA evidence showed pronounced effects on whether a case reached court and whether a jury found the accused guilty. If the case configurations are known, the calculations of conditional probability offer answers to questions such as "Will 
the case reach court?" and "Will a jury convict or exonerate?" The groups of cases in Table 5 illustrate how, in different case configurations, DNA evidence will alter the predicted court outcome, while in other cases, it will make little difference. Case scenarios with conditional predictions for guilty pleas and for the imposition of custodial penalties were omitted, as DNA was not calculated to be a predictor of these outcomes.

\section{TABLE 5}

Conditional Probabilities of Court Outcomes for Various Homicide Case Configurations at Different Stages without and with DNA Evidence

\begin{tabular}{|c|c|c|}
\hline Predictor & $\begin{array}{l}\text { Logit } \\
B_{0}+B_{1} \ldots+B_{1}\end{array}$ & $\begin{array}{l}\text { Probability } \\
1 / 1+e^{\text {logt }}\end{array}$ \\
\hline \multicolumn{3}{|l|}{ Whether case reaches court } \\
\hline \multicolumn{3}{|l|}{ Case 1 characteristics: } \\
\hline Without incriminating DNA evidence & 0.65 & 0.66 \\
\hline With incrim inating DNA evidence & 3.32 & 0.97 \\
\hline \multicolumn{3}{|l|}{ Case 2 characteristics: } \\
\hline \multicolumn{3}{|l|}{ Defendant male } \\
\hline Without incriminating DNA evidence & 2.26 & 0.91 \\
\hline With incriminating DNA evidence & 4.07 & 0.98 \\
\hline \multicolumn{3}{|l|}{ Jury Decision of Guilty } \\
\hline \multicolumn{3}{|l|}{ Case 3 characteristics: } \\
\hline \multicolumn{3}{|l|}{ Victim is male } \\
\hline \multicolumn{3}{|l|}{ No fingerprint evidence } \\
\hline \multicolumn{3}{|l|}{ Defendant refuses police interview } \\
\hline Without incriminating DNA evidence & -1.73 & 0.15 \\
\hline With incrim inating DNA evidence & 1.41 & 0.80 \\
\hline \multicolumn{3}{|l|}{ Case 4 characteristics: } \\
\hline \multicolumn{3}{|l|}{ Victim is female } \\
\hline \multicolumn{3}{|l|}{ No fingerprint evidence } \\
\hline \multicolumn{3}{|l|}{ Defendant refuses police interview } \\
\hline Without incriminating DNA evidence & -0.05 & 0.49 \\
\hline With incrim inating DNA evidence & 3.69 & 0.98 \\
\hline \multicolumn{3}{|l|}{ Case 5 characteristics: } \\
\hline \multicolumn{3}{|l|}{ Victim is male } \\
\hline \multicolumn{3}{|l|}{ No fingerprint evidence } \\
\hline \multicolumn{3}{|l|}{ Defendant confesses } \\
\hline Without incriminating DNA evidence & 0.20 & 0.55 \\
\hline With incriminating DNA evidence & 3.34 & 0.97 \\
\hline
\end{tabular}

In Case 1, where the defendant was female, the addition of incriminating DNA evidence increased the conditional probability from .66 to a much more robust .97 . In Case 2 with a male defendant, the prosecution's inclusion of DNA evidence made less difference to whether the case reached court, as the conditional probability value only increased from .91 to a near certainty of .99 . From Table 4 , it can be seen that the model correctly classified 93 percent of cases as to whether they would reach court. Case 3 illustrates how the addition of incriminating DNA evidence altered the conditional probability from .15 across the .50 
threshold to .80; that is, from a finding of not guilty to guilty. In Case 4 also, DNA evidence altered the predicted jury finding as it increased the conditional probability from borderline exoneration of .49 to a far more substantial probability of conviction of .96. In the final case in Table 5, the addition of DNA evidence acted to strengthen the probable outcome of conviction. The model correctly classified 81 percent of cases decided by juries. Cases decided by juries but not correctly classified would be influenced by individualising factors other than those taken into account by the model. These could include the effectiveness of defence and prosecution counsel, the nature of witness testimony, presence and types of directions given to the jury by the judge, and legal defences raised.

\section{Association with Length of Sentence}

Murder offences in Queensland attract a mandatory life sentence, so to test the fourth hypothesis only the lesser manslaughter offences, where the length of sentence can vary, were analysed. Standard or simultaneous multiple regression was used. The independent variables significantly associated with length of penalty for manslaughter offences were found to be DNA evidence, fingerprints and a guilty plea by the defendant. Values in the model summary were:

Number of cases $=48$ (26 with DNA, 22 without)

Multiple correlation coefficient, $\mathrm{R}=.63$

$\mathrm{R}$-squared $=.40$

Adjusted R-squared $=.35$

Standard Error of Estimate $=2.44$.

Lower and upper 95\% confidence intervals are shown in Table 6.

In Table 6, the Standardised Coefficient Beta value for DNA evidence of -0.45 (years) is interpreted to indicate that the inclusion of incriminating DNA evidence will be associated with a reduction in sentence of more than 5 months (Bohrnstedt \& Knoke, 1994, pp. 272280). A guilty plea showed a similar effect in predicting a sentence reduction. Lastly, fingerprint evidence was associated with an increased sentence length of 3 months $(0.25$ years). Explanations for the two types of forensic identification evidence having associations in different directions will be sought in the section that follows.

\section{TABLE 6}

Regression Coefficients for Penalty Amount - Manslaughter Offences $(\mathrm{N}=43)$

\begin{tabular}{cccccccc}
\hline Variable & $\begin{array}{c}\text { Unstand. } \\
\text { Coef. }\end{array}$ & \multicolumn{3}{c}{$\begin{array}{c}\text { Stand. } \\
\text { Coef. }\end{array}$} & & Sig. of B & \multicolumn{2}{c}{$95 \%$ Cl } \\
& B & $\begin{array}{c}\text { Std. } \\
\text { Error }\end{array}$ & Beta & & & & Upper \\
\hline & 10.92 & .85 & & 12.80 & .000 & 9.19 & 12.64 \\
(Constant) & 1.79 & .88 & .25 & 2.02 & .050 & -.002 & 3.58 \\
Fingerprints & 1.79 & .76 & -0.45 & -3.54 & .001 & -4.23 & -1.15 \\
DNA & -2.69 & .76 & -0.23 & \\
Guilty plea & -2.60 & .79 & -0.41 & -3.28 & .002 & -4.20 & -1.00 \\
\hline
\end{tabular}

Nole: Dependent Variable: Penclity amount in years. 


\section{Analysis and Discussion: Findings in Relation to Hypotheses}

\section{Effects on Cases Reaching Court}

Two independent variables were found to be significant predictors of cases reaching court: DNA evidence and the accused being male. The first hypothesis was therefore validated. DNA evidence did lead to a higher proportion of homicide cases reaching court. However, as only 11 cases did not go to trial, caution is strongly advised in interpreting results from such a small sample. Table 4 indicates that DNA evidence was a significant predictor of decisions by the Office of the Department of Public Prosecutions (DPP) to prosecute, with the odds ratio showing that such cases were much more likely to reach court than cases without DNA evidence: the odds of a case reaching court were more than 14 (14.69) times higher where there was DNA evidence than where there was not. Explanations for the other predictor of cases reaching court - defendants being male - were sought in criminological theory and through an examination of the anomalous cases in the sample - those involving female defendants. One theoretical explanation has contended that there is "systematic chivalric bias ... which showed women offenders receiving more sympathetic and individualized justice for serious crimes for which men got no comparable understanding" (Heidensohn, 1997, p. 778; see also Chan, 2001).

An examination of the cases sampled revealed that a high proportion, 124 of 148 known (84\%), involved male defendants. Of 26 females charged, however, four of those cases (15\%), all from the control group, did not reach court. Two of these cases were infanticides: in one case where a 14-month-old was stabbed to death and the prosecution offered no evidence at committal. The other case involved a "shaken baby syndrome" death. In the latter case, the mother denied responsibility while other persons had access to the child and the case was nolled by the DPP. Unlike New South Wales, Victoria and Canada, Queensland has never legislated a specific offence of infanticide, where the penalty is commonly noncustodial and includes psychiatric treatment (Potas, 1984, p. 8).

The other two cases with female accused that did not reach court were related to domestic disputes. In one case, no evidence was offered in the magistrates' court, while the other was nolled in the Supreme Court. As was found below with jury decisions in DNA evidence cases, females charged with homicides associated with domestic violence were frequently acquitted, thereby supporting the explanation of chivalric bias. It is not unexpected in these two instances then that prosecutors should withdraw such cases due to the perceived likelihood of similar such acquittals.

\section{Effects on Guilty Pleas}

As previously found with sexual offences and serious assaults (Briody, 2002b, 2002c; Taupin, 1994, p. iv), DNA evidence did not act as a predictor or have a significant association with guilty pleas. The second hypothesis was therefore discounted. The strongest predictor of a guilty plea, although negative, was the seriousness of the offence; that is, manslaughter offences were associated with guilty pleas. Other predictors were younger victim age, if the defendant made no statement to police or refused an interview and if defendants were Indigenous (from Table 4).

The association between manslaughter charges and guilty pleas was attributed to two factors. First, murder charges did not attract a guilty plea because of the mandatory life sentence imposed in Queensland; that is, prosecutors could not offer defendants any reduction in the penalty in return for a guilty plea (Zdenkowski, 1994, p. 171). The imposition of proportionate penalties as a preferable alternative has been proposed (Wood, 
1992). Second, many murder cases that were nolled were found in the criminal history records to be presented in another indictment as manslaughter charges, which were in turn accompanied by a guilty plea.

A second significant but negative predictor of a guilty plea was the age of the victim at the time of the offence. A guilty plea was more likely where the victim was under the median age of 35 years. Cases where victims were under the median age were four times more likely to result in a guilty plea than where victims were older. This result might be influenced by the presence of child victims - $8 \%$ of victims in the sample were aged between 4 months and 12 years, with guilty pleas entered in nearly all cases. Self-defence or provocation would not be viable defences at trial in such cases, possibly leaving offenders little alternative but to plead guilty. Additional factors that may contribute to the plea decision include remorse at having killed a child (often their own), reluctance to face a public trial and a wish to expedite the legal process so as to deal with feelings of guilt (Alder \& Polk, 2001; Stroud \& Pritchard, 2001, pp. 249-269).

A third negative predictor of guilty pleas was where the defendant made no statement to police or refused a police interview. Cases with this variable were over three times less likely to culminate in a plea of guilty than cases where defendants were interviewed. One objective of police interviews is to explore and possibly negate defences of a suspect, as provided for in the exculpatory sections in the Queensland Criminal Code 1899 (see also Victorian Law Reform Commission, 2002). By making no statement or refusing a police interview, often on legal advice, any defence later raised by the accused either will by then have had the benefit of legal counsel, or the defendant will have gained time to prepare a defence strategy.

Where defendants were Indigenous, they were marginally more likely to plead guilty than other defendants, instead of opting for trial. Although Indigenous people formed close to $3 \%$ of the State's population at 30 June 1996 , they formed $28 \%$ of the defendants in the cases sampled (from Table 1). According to an opinion by researcher Jenny Mouzos (2002c) about higher plea rates,

this may be a function of the actual "type" of homicides committed by Indigenous persons ... A comparative analysis of Indigenous and non-Indigenous homicides in Australia revealed that Indigenous homicides are quantitatively different from non-Indigenous homicides - that is, they are more likely to occur between persons known to one another, usually family or intimates, and significantly less likely to involve the use of firearms. Many of them are usually solved quite early in the investigation, as the offender is usually known to the victim and witnesses. While we know that Indigenous homicides are quite different from nonIndigenous homicides, there may of course be other factors responsible for the higher guilty pleas in murder: are solicitors representing Indigenous clients more likely to advise their clients to plead guilty than solicitors representing nonIndigenous clients? ... Given the nature of Indigenous homicides, evidence would not be lacking (i.e., the death of the victim is likely to be bought to the attention of police within a short time after it was committed, instead of days, weeks or even months after the incident) (Personal communication, December, 20, 2002; see also Eames, 1992; Martin, 1992; Mouzos, 2001).

\section{Effects on Jury Decisions}

As with other major offence types, DNA evidence in homicide cases was found to exert a strong influence on jurors' decisions to convict, the odds of a conviction being much higher for cases with DNA than for cases without. Incriminating fingerprints also strongly 
influenced juries to convict. However, the wide confidence intervals for DNA and fingerprints, resulting from the relatively small number of cases on which the model is based $(\mathrm{N}=63)$, make any conclusions or predictions that use them of dubious quality, and caution is advised when referring to the model. Juries were responsible for deciding two-thirds of the cases prosecuted (92 of 142 known). In comparing these two methods of identification, Rhonda Wheate, a lawyer ascertaining how well juries cope with complex forensic evidence, believes that for juries, "Fingerprints have the great advantage specifically over DNA evidence in that everybody can see their own fingerprint" (ABC Radio National, The Law Report, August, 27, 2002).

Other predictors of jury decisions were the sex of the victim and recorded statements, both confessions and denials, by the accused to police. This contrasted with findings about DNA evidence in sexual offences and serious assault cases, where confessions acted instead as a predictor of guilty pleas (Briody, 2002b, 2002c). This is probably best explained, as before, by the mandatory life sentence for murder, where there is no incentive by way of reduced penalty for pleading guilty. So, although having confessed to police, many accused still chose to go to trial. While an accused may plead not guilty in court, a prosecutor's presentation of a videotaped police record of interview, where the accused has confessed to the crime, can have a decisive influence on a jury, making a conviction more likely than in cases without a confession - the odds of a conviction being six times higher with a confession than without (from Table 4).

The seven cases with DNA evidence where juries acquitted were examined to ascertain reasons, isolate common factors and detect anomalies. Common factors in four of the cases were that the deaths occurred during domestic disputes and all four accused were Indigenous females. Three of the victims in these cases were males of Indigenous race and one was a male Caucasian. Table 2 indicates the significant negative association of such cases with jury convictions; that is, their strong association with acquittals. This association applied both to Indigenous defendants and to female defendants enmeshed with the victim. Killings among Indigenous people have been found to be "more likely to occur within the family environment, with a high proportion of female involvement (both as victims and offenders)" (Mouzos, 2001, p. 1). In two of the cases sampled the accused refused a police interview, but the other two accused admitted to causing the deaths to police. An outline of one such case, along with an opinion from the investigating police officer follows:

Case H33: DNA evidence was profiled from blood on the clothes of the accused and matched to the profile of blood of the victim. The suspect refused a formal record of interview, but police recorded her admissions to the killing on tape and in their notebooks. The Investigating Officer's brief reply to a query about his view of the case in the Circuit Court was: Case was simple. She argued, went into a locked room in a nearby house, got a knife, came back out and stabbed him once. DEAD. All that can be said was that it was a [city] jury, and Aboriginal on Aboriginal. I do recall that DV [domestic violence] matters and selfdefence/provocation were mentioned during the trial (Forensic Biology Laboratory Case File No. F19183; QPS CRISP; Police Prosecution Magistrates Court Brief [QP9A]; Plain Clothes Senior Sergeant G. Hurst, personal communication, November, 11, 2002).

Theoretical explanations relevant to these cases are available. Bradfield (2001) has studied spousal-related homicides by women, particularly in domestic violence situations, emphasising lack of intent and diminished responsibility, while Mouzos $(1999,2001)$ as noted, has investigated homicides among Indigenous people. The remaining cases where juries acquitted despite DNA evidence were largely circumstantial. One involved the disappearance of Bowen schoolgirl Rachel Antonio and was widely publicised. Comments 
by counsel for the defence in the appeal illustrate the importance they assigned to DNA evidence:

Case H47: On Anzac Day 1998, the 16-year-old disappeared on her way to the movies. Despite the absence of a corpus delicti, a case was brought against a man in his twenties, who was alleged to have had a relationship with the missing girl. The suspect denied the offence. A police search of his belongings resulted in a spot of blood being found on a sandal. The blood was profiled for DNA and matched to the profile from hair taken from a hairbrush belonging to the vanished teenager and consistent with DNA samples taken from her relatives. The accused went to trial twice. The first trial ended in November 1999, in the Townsville Supreme Court, with the accused being found guilty of manslaughter and sentenced to imprisonment for nine years. In August 2000, the Court of Appeal set aside this conviction and ordered a new trial. In arguing before the Court of Appeal for the conviction to be quashed, Walter Sofronoff QC "argued the DNA evidence was so powerful, from an emotional sense, it had to impact on the jury decision" (Oberhardt, 2000b: 5, emphasis added). Sofronoff further argued that the blood found on the sandal of the accused could not be aged. For the Crown, Michael Byrne QC stated that there had been no objection to the DNA evidence during the original trial. A second trial, however, was ordered. In this, the defence introduced its own expert witness to testify on the DNA evidence. The second trial ran for three weeks, and on 16 June 2001 the jury of six men and six women absolved the accused (Ketchell, 2001, p. 4; Oberhardt, 2000b, p. 5; Scholz, 2001, p. 3).

The third hypothesis, about the impact of DNA evidence upon jurors, was therefore verified from the statistical analysis.

\section{Prediction of Custodial Penalties}

The gravity of the offences in homicide cases ensured that all found guilty were incarcerated, whether for murder or for manslaughter. In effect, a guilty verdict was the sole predictor of custodial penalties. DNA therefore was not tested as a predictor of custodial penalties. The only case encountered where imprisonment was not imposed was not included in the sample studied, as it did not meet the selection criterion listed earlier for adult penalties because it involved a child offender. In that case, a 13-year-old who was babysitting her 4-year-old stepbrother smothered him in an attempt to stop him crying. A 2year good behaviour period was imposed.

\section{Association with Length of Penalty: Manslaughter Cases}

Sentences in Queensland are imposed in the Supreme Court under the Penalties and Sentencing Act 1992 and judicial discretion is limited both as to the imposition of custodial sentences and to a lesser extent, on the length of sentences. Sentencing guidelines are contained in section 9 of the Act, while section 13 requires that a guilty plea be taken into account and may reduce the sentence. The Act may be used in conjunction with the Queensland Sentencing Manual (Robertson \& Mackenzie, 1998). However, in previous control-comparison studies both DNA and other types of forensic evidence have been found to be associated with longer penalties (Briody, 2002b, p. 177; Peterson et al., 1987, p. 1730). In the multiple regression analysis above, it was calculated that the length of custodial penalties in manslaughter cases was significantly but negatively associated with DNA evidence, as were guilty pleas (from Table 6). While DNA was associated with a shorter sentence length of about 5 months, fingerprints were correlated with an increase of 3 months. 
Peterson et al. attributed the association of heavier penalties with forensic evidence in the US to a greater certainty about guilt in the minds of those imposing sentences (1987, p. 1743), although this reasoning would not apply in the Queensland situation. Other explanations point to the timing factor and immediacy of reporting the offence. With the early reporting of a crime, and quick results from the analysis of forensic identification evidence, witnesses can be interviewed and alibis may be negated, resulting in a stronger overall case leading to heavier penalties (Gaule, 1999, p. 2). One possibility for the apparent paradoxical result of the two types of forensic identification evidence acting in different directions is that the multiple regression analysis was confounded by disproportionate penalties for the manslaughter cases that were originally charged as murders.

Results from the present research though, would suggest that identifications from fingerprint evidence were more quickly available than those from DNA. This theoretical explanation was confirmed, in that fingerprint comparison results were provided to homicide investigators within hours or days (Acting Inspector P. Feldman, personal communication), whereas DNA analysis results took weeks or months in the cases sampled. Further research is indicated to determine reasons for the unusual negative association of DNA with sentencing length. No empirical support was found for the fourth hypothesis. However, DNA evidence did show a significant statistical association with penalty length for manslaughter cases.

\section{Conclusion}

This study found that in homicide cases in Queensland, DNA evidence presented by prosecutors acted as the most significant predictor of cases reaching court, followed by whether the defendant was male. For explaining guilty pleas, the most important variable in homicide cases was the seriousness of the charge: the accused were four times more likely to plead guilty to a manslaughter charge than to one of murder, most likely because of the mandatory life sentence attached to murder. Defendants were also more likely to plead guilty where they were Indigenous or where victims were younger. Guilty pleas were less likely where the accused had made no statement to police. As with control-comparison studies of sexual offences and serious assaults involving DNA evidence, there was no statistically significant association found between DNA and guilty pleas in the homicide cases sampled. These consistent findings for several types of serious offences suggest that the CrimTrac national DNA business case (Nearhos \& Bowman, 1999, p. 69) may need some revision, as it projects cost savings based on increases in guilty pleas attributed to DNA usage.

Juries were more likely to convict where the prosecution used DNA evidence than when it did not. Fingerprint evidence and a confession added to the likelihood of a guilty finding. Juries were more likely to acquit where the accused had denied guilt in a police record of interview or was female. The addition of DNA evidence in particular case configurations was found to alter the predicted jury decision from an acquittal to a conviction. DNA evidence demonstrated an unusual negative association with length of sentences in manslaughter cases.

Policy implications from these findings on defendants' plea decisions are that legislators may need to consider alternative sentencing options: proportionate sentencing may be appropriate in some situations, such as domestic homicides where diminished responsibility is shown. A separate offence of infanticide, as legislated in southern States, may be worth considering. Further study on DNA evidence in homicide cases in other jurisdictions is suggested for comparison with Queensland results. Future quantitative studies are also needed to assess reliably the effectiveness of DNA and databases in the area where its 
application is currently enjoying rapid expansion: by examining how well it helps achieve convictions for, and can contribute to controlling, property crimes.

\section{Acknowledgements}

The author would like to thank Hennessey Hayes and Tim Prenzler of Griffith University's School of Criminology and Criminal Justice; Leo Freney and Peter Clausen of Queensland Health's Forensic Biology Section; the Queensland Police Service (QPS), particularly staff of the Research Committee and of the Police Information Centre; and two anonymous referees. Opinions expressed are not those of the QPS.

\section{References}

Alder, C. \& Polk, K. (2001). Child victims of homicide. Melbourne: Cambridge University Press.

Bohrnstedt, G. \& Knoke, D. (1994). Statistics for social data analysis. Itasca, IL: F.E. Peacock Publishers Inc.

Bradfield, R. (2001). Women who kill: Lack of intent and diminished responsibility as the other "defences" to spousal homicide. Current Issues in Criminal Justice, 13(2), 143-167.

Briody, M. (2002a). The effect of DNA evidence on arrests and investigations in sexual offence cases. Forensic Bulletin, June, 24-25. Retrieved September, 2, 2002, from http://www.nifs.com. au/Publications/Jun02/NIFSBulletin_pp15-28.pdf

Briody, M. (2002b). The effects of DNA evidence on sexual offences in court. Current Issues in Criminal Justice, 14(2), 159-181.

Briody, M. (2002c). The effects of DNA evidence on serious assault cases in court. $\mathrm{PhD}$ Research, School of Criminology and Criminal Justice, Griffith University, Brisbane.

Chan, W. (2001). Women, murder and justice. Basingstoke: Palgraves.

Coelli, A. (1989). First Australian conviction using DNA fingerprinting. Australian Law News, September, 22-26.

Connors, E., Lundregan, T., Miller, N., \& McEwan, T. (1996). Convicted by juries, exonerated by science: Case studies in the use of DNA evidence to establish innocence after trial. Alexandria, VA: National Institute of Justice, US Department of Justice.

Criminal Code 1899 (Queensland).

Criminal Investigations (Blood Samples) Act 1995 (New Zealand).

Eames, G. (1992, May). Aboriginal homicide: Customary law defences or customary lawyers' defences? Proceedings of Homicide: Patterns, Prevention and Control Conference. Canberra: Australian Institute of Criminology.

Gaule, M. (1999). Identifying the effects of timeliness of DNA crime stain analysis on resultant detections. Sussex [UK] Police/ Forensic Science Service.

Hansen, P. (2001, February 4). Battle of the Boffins: Murder trial focuses on DNA test. The Sunday Mail, p. 15.

Heidensohn, F. (1997). Gender and crime. In M. Maguire, R. Morgan, \& R. Reiner (Eds.), The Oxford handbook of criminology (pp. 761-799). Oxford: Clarendon Press.

Inman, K. \& Rudin, N. (1997). An introduction to forensic DNA analysis. New York: CRC Press. Ketchell, M. (2001, June 17). Family weeps as Hytch cleared. The Sunday Mail, p. 4.

Locard, E. (1934). Manuel de technique policere (2nd ed.). Paris: Payot.

Martin, D. (1992, May). Aboriginal and non-Aboriginal homicide: "Same but different". Proceedings of Homicide: Patterns, Prevention and Control Conference. Canberra: Australian Institute of Criminology.

Mobbs, J. (2001, April). The National Criminal DNA Database - An investigative tool for the future. Use of DNA in the Criminal Justice System, Seminar Papers, Sydney University Law School. 
Mouzos, J. (1999, November). New statistics highlight high homicide rate for Indigenous women. Indigenous Law Bulletin, 4(25), 16-17.

Mouzos, J. (2000). Homicidal encounters: A study of homicide in Australia 1989-1999. Australian Institute of Criminology, Research and public policy series No. 28, Canberra.

Mouzos, J. (2001). Indigenous and non-Indigenous homicides in Australia: A comparative analysis. Australian Institute of Criminology Trends and issues in crime and criminal justice No. 210, Canberra.

Mouzos, J. (2002a). Homicide. In A. Graycar \& P. Grabosky (Eds.), The Cambridge handbook of Australian criminology (pp. 157-195). Cambridge: Cambridge University Press.

Mouzos, J. (2002b). Homicide in Australia: 2000-2001 National Homicide Monitoring Program (NHMP) annual report. Canberra: Australian Institute of Criminology.

Nearhos, M., \& Bowman, J. (1999). CrimTrac National DNA Criminal Investigation System Business Case. Canberra: Attorney-General's Department, Law Enforcement Coordination Division.

Nolan, J. (2001, February 17). DNA slams door on killer's freedom. The Courier-Mail, p. 12.

Oberhardt, M. (1999, July 31). Accused should fear DNA data, court told. The Courier-Mail, p. 7. Oberhardt, M. (2000a). DNA bungle claimed in cat woman appeal case, The Courier Mail, 23 May 2000, 11.

Oberhardt, M. (2000b). DNA appeal in Bowen killing case, The Courier Mail, 11 May 2000, 5. Oberhardt, M. (2001). Life sentence for Brampton murder, The Courier Mail, 14 February 2001, 3 .

Penalties and Sentencing Act 1992 (Queensland).

Peterson, J., Mihajlovic, S., \& Gilliland, M. (1984). Forensic evidence and the police: The effects of scientific evidence on criminal investigations. Alexandria, VA: National Institute of Justice, US Department of Justice.

Peterson, J., Ryan, J., Houlden, P., \& Mihajlovic, S. (1987). The uses and effects of forensic science in the adjudication of felony cases. Journal of Forensic Sciences, 32(6), $1730-1753$.

Polk, K. (1994). When men kill: Scenarios of masculine violence. Melbourne: Cambridge University Press.

Potas, I. (1984, May). Sentencing murderers. Paper presented at the 54th ANZAAS Congress, Canberra.

Poulos, T. (1993). Logistic regression: Application of advanced statistical methods to criminal justice issues. Richmond, VA: Criminal Justice Research Center, Department of Criminal Justice Services.

Robertson, J., \& Mackenzie, G. (1998). Queensland sentencing manual. North Ryde: Law Book Company Information Services.

Scholz, N. (2001, June 9). DNA doubt raised in killing trial. The Courier-Mail, p. 3.

Scott, L. (1999, September 9). Trial by acid test. The Australian, p. 9.

Speakman, M. (1999). Evaluation of DNA. Association of Chief Police Officers/Forensic Science Service, Report by Humberside Police.

Stroud, J., \& Pritchard, C. (2001). Child homicide, psychiatric disorder and dangerousness: A review and an empirical approach. British Journal of Social Work, 31, 249-269.

Tabachnick, B., \& Fidell, L. (2001). Using multivariate statistics. Needham Heights, MA: Allyn \&Bacon.

Taupin, J. (1994). The impact of DNA profiling on the criminal justice system. Unpublished master's thesis, Department of Criminology, University of Melbourne.

Thomas, H. (2002, March 30). Blinded by science. The Courier-Mail, p. 28.

Tracy, P., \& Morgan, V. (2000). Big Brother and his science kit: DNA databases for 21st century crime control. The Journal of Criminal Law and Criminology, 90(2), 635690.

Victorian Law Reform Commission. (2002). Defences to homicide: Issues paper. Melbourne: Author. 
Wambaugh, J. (1989). The Blooding. London: Bantam.

Wheate, R. (2002). Judging juries - Part 2. The law report, ABC Radio National, August 27, 2002. Retrieved December 28, 2002 from www.abc.net.au/rn/talks/8.30/lawrpt/stories/s658458.htm

White, R., \& Perrone, S. (1997). Crime and social control. Melbourne: Oxford University Press.

Wilson-Wilde, L. (2001, April). DNA profiling and its impact on policing. Use of DNA in the criminal justice system (Papers from a Public Seminar). Sydney: Institute of Criminology, Sydney University Law School.

Wood, D. (1992, May). The abolition of mandatory life imprisonment for murder: Some jurisprudential issues. Proceedings of Homicide: Patterns, Prevention and Control Conference. Canberra: Australian Institute of Criminology.

Zdenkowski, G. (1994). Contemporary sentencing issues. In D. Chappell \& P. Wilson (Eds.), The Australian criminal justice system, the mid 1990s. Sydney: Butterworths. 